\title{
PENGUJIAN KEPUTUSAN OLEH PENGADILAN TATA USAHA NEGARA TERHADAP DISKRESI YANG DILAKUKAN OLEH PEJABAT PEMERINTAHAN
}

\author{
Rahmad Tobrani \\ Program Magister Ilmu Hukum Universitas Syiah Kuala \\ Jl. Putroe Phang No. 1, Darussalam, Banda Aceh, 23111 \\ boyrahmadtobrani@gmail.com
}

\begin{abstract}
Abstrak, Diskresi adalah keputusan dan/atau tindakan yang ditetapkan dan/atau dilakukan oleh Pejabat Pemerintahan untuk mengatasi persoalan konkret yang dihadapi dalam penyelenggaraan pemerintahan dalam hal peraturan perundang-undangan yang memberikan pilihan, tidak mengatur, tidak lengkap atau tidak jelas, dan/atau adanya stagnasi pemerintahan. Hasil penelitian ini secara praktis diharapkan dapat menjadi acuan yang dapat menunjang tugas Badan/Pejabat Pemerintahan dalam menerbitkan keputusan diskresi, sebaliknya bagi Pengadilan Tata Usaha Negara agar memiliki acuan dalam menguji keputusan-keputusan yang lahir dari kewenangan diskresi. Dasar diterbitkannya keputusan diskresi adalah adanya "keadaan mendesak" dan pengujian terhadap keputusan diskresi oleh Pengadilan Tata Usaha Negara dilakukan tidak dengan menggunakan peraturan perundangundangan yang berlaku, melainkan dengan asas-asas umum pemerintahan yang baik (AAUPB). Produk hukum dari badan/pejabat pemerintahan yang dapat dijadikan objek segketa dan diuji pada pengadilan Tata Usaha Negara berupa keputusan (beschikking).
\end{abstract}

\section{Kata Kunci : Keputusan Diskresi, Pejabat Pemerintahan , Pengadilan Tata Usaha} Negara

\begin{abstract}
Discretion is a decision and/or action determined and/or performed by Government Officials to address the concrete issues faced in governing governance in terms of choice, non-regulating, incomplete or unclear legislation and/or government stagnation. The results of this study are practically expected to be a reference that can support the duty of the Agency / Government Officials in issuing discretionary decisions, in contrast to the State Administrative Court to have a reference in testing decisions arising from the discretion authority. The basis of the discretionary decree is the existence of "urgent circumstances" and the examination of discretionary decisions by the State Administrative Court is conducted not by applying the prevailing laws but with the general principles of good governance (AAUPB). Legal products of governmental agencies/officials that can be used as dispute objects and tested in the State Administrative Court in the form of decision (beschikking).
\end{abstract}

Keywords: Discretion Decision, Govermental Officials, State's Administrative Court

\section{Pendahuluan}

Dalam menjalankan pemerintahan, Pemerintah telah dilengkapi dengan tugas dan fungsi berupa kewenangan baik yang bersifat atributif maupun yang bersifat delegatif. 
Volume 13, Nomor 1, Januari-Juni 2018

Dengan adanya perkembangan masyarakat, maka seringkali terdapat keadaankeadaan tertentu/mendesak yang membuat Pajabat/Badan administrasi pemerintahan tidak dapat menggunakan kewenangannya khususnya kewenangan yang bersifat terikat (gebonden bevoegheid), dalam melakukan tindakan hukum dan tindakan faktual secara normal.

Sebagai negara yang bertujuan untuk memajukan kesejahteraan umum, melekatnya fungsi memajukan kesejahteraan umum dalam welfare state (negara kesejahteraan) menimbulkan beberapa konsekuensi terhadap penyelenggaraan pemerintahan yaitu pemerintah harus berperan aktif mencampuri bidang kehidupan sosial ekonomi masyarakat. Untuk itu kepada pemerintah dilimpahkan bestuurszorg atau public service agar servis publik dapat dilaksanakan dan mencapai hasil maksimal, kepada administrasi negara diberikan suatu kemerdekaan tertentu untuk bertindak atas inisiatif sendiri menyelesaikan berbagai permasalahan pelik yang membutuhkan penanganan secara cepat, sementara terhadap permasalahan itu tidak ada, atau masih belum dibentuk suatu dasar hukum penyelesaiannya oleh lembaga legislatif $1^{1}$ yang kemudian dalam hukum administrasi negara diberikan kewenangan bebas berupa diskresi.

SF Marbun ${ }^{2}$ mengatakan bahwa dengan diberikannya kebebasan bertindak (freies ermessen) kepada administrasi negara dalam melaksanakan tugasnya mewujudkan welfare state atau social rechtstaat di Belanda sempat menimbulkan kekhawatiran bahwa akibat dari freies ermessen akan menimbulkan kerugian bagi warga masyarakat. Oleh karena itu untuk meningkatkan perlindungan hukum bagi warga masyarakat, pada tahun 1950, Panitia de Monchy di Netherland membuat laporan tentang asas-asas umum pemerintahan yang baik atau algemene beginselen van behoorlijk bestuur. Pada mulanya timbul keberatan dari pejabatpejabat dan pegawai-pegawai pemerintah di Netherland karena ada kekhawatiran bahwa Hakim atau Pengadilan Administrasi kelak akan mempergunakan istilah itu untuk memberikan penilaian terhadap kebijaksanaankebijaksanaan yang diambil pemerintah, namun keberatan demikian sekarang ini telah lenyap ditelan masa karena telah hilang relevansinya. ${ }^{3}$

Marcus Lukman sebagaimana dikutip oleh Saut P Panjaitan ${ }^{4}$ mengatakan bahwa persoalan-persoalan penting yang mendesak, sekurang-kurangnya mengandung unsurunsur sebagai berikut :

1 Patuan Sinaga, Hubungan antara kekuasaan dengan Pouvoir Discretionnaire Dalam Penyelenggaraan Pemerintahan dalam SF Marbun dkk, Dimensi-Dimensi Pemikiran Hukum Administrasi Negara, (Yogyakarta: UII Press, 2001), hlm73

${ }^{2}$ SF Marbun, Menggali dan Menemukan Asas-asas Umum Pemerintahan yang Baik Di Indonesia, dalam SF Marbun dkk, Dimensi-Dimensi Pemikiran Hukum Administrasi Negara, (Yogyakarta: UII Press, 2001), hlm 205

3 Zaki Ulya, Pertanggungjawaban Pejabat Pemerintahan dalam Menetapkan Diskresi (Studi terhadap Putusan Mahkamah Konstitusi Nomor 25/PUU-XIV/2016), Jurnal Ius Quia Iustum, Vol 24, No 3, 2017, hlm. 413

${ }^{4}$ Marcus Lukman sebagaimana dikutip oleh Saut P. Panjaitan, Makna dan Peranan Freies Ermessen Dalam Hukum Administrasi Negara dalam SF Marbun dkk, Dimensi-Dimensi Pemikiran Hukum Administrasi Negara, (Yogyakarta: UII Press, 2001), hlm 117 
Volume 13, Nomor 1, Januari-Juni 2018

a. Persoalan-persoalan yang muncul harus menyangkut kepentingan umum, yaitu: kepentingan bangsa dan negara, kepentingan masyarakat luas, kepentingan rakyat banyak/bersama, serta kepentingan pembangunan.

b. Munculnya persoalan tersebut secara tiba-tiba, berada diluar rencana yang telah ditentukan.

c. c.Untuk menyelesaikan persoalan tersebut, peraturan perundang-undangan belum mengaturnya atau hanya mengatur secara umum, sehingga administrasi negara mempunyai kebebasan untuk menyelesaikan atas inisiatif sendiri.

d. Prosedurnya tidak dapat diselesaikan menurut administrasi yang normal, atau jika diselesaikan menurut prosedur administrasi yang normal justru kurang berdaya guna dan berhasil guna.

e. Jika persoalan tersebut tidak diselesaikan dengan cepat, maka akan menimbulkan kerugian bagi kepentingan umum.

Menurut Anna Erliyana, penggunaan freies ermessen oleh Badan/Pejabat administrasi negara dimaksudkan untuk menyelesaikan persoalan-persoalan penting dan mendesak serta tiba-tiba yang sifatnya kumulatif. Bisa saja muncul persoalan yang penting tapi tidak mendesak untuk segera diselesaikan. Ada pula kemungkinan muncul persoalan mendesak, tapi tidak terlalu penting untuk diselesaikan. Suatu persoalan baru dapat dikualifikasi sebagai persoalan penting apabila persoalan tersebut menyangkut kepentingan umum, sedangkan kriteria kepentingan umum harus ditetapkan oleh suatu peraturan perundang-undangan ${ }^{5}$.

Muhammad Siddiq Armia dalam tulisannya menyebutkan posisi peradilan memainkan peranan penting dalam proses uji materi undang-undang. ${ }^{6}$ Dan, untuk menguji kebijakan pemerintah salah satunya Peradilan Tata Usaha Negara. Sebelum membahas mengenai dasar pengujian Pengadilan Tata Usaha Negara, perlu diketahui dahulu kewenangan Pengadilan Tata Usaha Negara berdasarkan Undang-undang Nomor 5 tahun 1986 sebagaimana yang diubah dengan Undang-undang Nomor 9 tahun 2004 dan Undang-Undang Nomor 51 Tahun 2009 tentang Peradilan tata Usaha Negara serta berdasarkan UU Nomor 30 tahun 2014 tentang Administrasi Pemerintahan. Berdasarkan Pasal 47 jo Pasal 50 Undang-Undang Peradilan Tata Usaha Negara maka kewenangan Pengadilan Tata Usaha Negara adalah memeriksa, mengadili dan menyelesaikan sengketa tata usaha negara pada tingkat pertama.

Selanjutnya Pasal 1 angka 10 Undang-Undang Nomor 51 Tahun 2009 tentang Peradilan tata Uaha Negara menyebutkan bahwa sengketa tata usaha negara adalah sengketa yang timbul dalam bidang tata usaha negara antara orang atau badan hukum perdata dengan badan atau pejabat tata usaha negara, baik di pusat maupun di daerah

5 Anna Erliyanna, Keputusan Presiden, Analisis Keppres RI 1987-1998, Program Pasca Sarjana Fakultas Hukum Universitas Indonesia, Universitas Indonesia Fakultas Hukum Pasca Sarjana Jakarta, 2005 hlm 38

6 Muhammad Siddiq Armia, Mahkamah Konstitusi Dan Pengujian Undang-Undang: Pembelajaran Bagi Indonesia, Jurnal NEGARA HUKUM: Vol. 8, No. 1, Juni 2017, hlm. 107 
Volume 13, Nomor 1, Januari-Juni 2018

sebagai akibat dikeluarkannya keputusan tata usaha negara, termasuk sengketa kepegawaian berdasarkan peraturan perundang-undangan yang berlaku.

Dengan demikian, lingkup kewenangan Pengadilan Tata Usaha Negara saat ini adalah hanya terbatas pada pengujian terhadap Keputusan Tata Usaha Negara (beschikking), sedangkan tindakan faktual yang sering menjadi perbuatan melawan hukum oleh pemerintah belum menjadi kewenangan PTUN untuk memeriksa dan mengadilinya dan dalam perkembangannya, Undang-Undang Nomor 30 tahun 2014 tentang Administrasi Pemerintahan memperluas kewenangan absolut Pengadilan Tata Usaha Negara melalui Pasal 87 Undang-Undang Nomor 30 Tahun 2014 Tentang Administrasi Pemerintahan menyebutkan bahwa Keputusan tata usaha negara sebagaimana dimaksud dalam Undang-undang Nomor 5 tahun 1986 sebagaimana yang diubah dengan Undang-undang Nomor 9 tahun 2004 dan Undang-Undang Nomor 51 Tahun 2009 tentang Peradilan tata Usaha Negara harus dimaknai sebagai:

a. penetapan tertulis yang juga mencakup tindakan faktual;

b. Keputusan Badan dan/atau Pejabat Tata Usaha Negara di lingkungan eksekutif, legislatif, yudikatif, dan penyelenggara negara lainnya;

c. berdasarkan ketentuan perundang-undangan dan AUPB;

d. bersifat final dalam arti lebih luas;

e. Keputusan yang berpotensi menimbulkan akibat hukum; dan/atau

f. Keputusan yang berlaku bagi Warga Masyarakat;

Dengan adanya tambahan kewenangan untuk menguji perkara-perkara yang berkaitan dengan tindakan badan atau pejabat pemerintahan dan atau badan hukum lainnya yang menimbulkan kerugian material maupun immaterial, maka semakin lengkap fungsi Pengadilan Tata Usaha Negara sebagai fungsi kontrol yuridis terhadap pemerintah. Lintong Oloan Siahaan ${ }^{7}$ mengatakan bahwa Pemerintah sebagai pelayan (public service) mempunyai kekuasaan (power) untuk melaksanakan tugas pelayanannya tadi, yang apabila disalahgunakan akan menjadi fatal akibatnya dari segi hukum. Untuk itu perlu adanya kontrol, yang dengan demikian kemungkinan akan adanya penyalahgunaan kekuasaan, kesewenangwenangan dan lain-lain dapat dihindari atau diperkecil kemungkinan. Didalam literatur yang lain beliau menyebutkan bahwa kontrol yuridis merupakan bagian dari kontrol lain-lainnya terhadap pemerintah seperti kontrol politis, kontrol melalui tromol-tromol pos, kontrol intern administrasi, kontrol ekstern organisasi/lembaga baik yang struktural maupun non struktural ${ }^{8}$.

Selanjutnya sebagai dasar untuk melakukan pengujian terhadap keputusan diskresi, Pengadilan Tata Usaha Negara yang akan diamanatkan oleh pasal 1 angka 10 Undangundang Peradilan Tata Usaha Negara, pasal 1 angka 18 dan Pasal 87 Undang-Undang Nomor 30 tahun 2014 tentang Administrasi Pemerintahan yang menyebutkan keputusan

${ }^{7}$ Lintong Oloan Siahaan, Wewenang PTUN menunda berlakunya Keputusan Pemerintah, Perum Percetakan Negara RI, (Jakarta: Perum. Percetakan Negara RI, 2006), hlm 10

8 Lintong Oloan Siahaan, Prospek PTUN sebagai Pranata Penyelesaian Sengketa Administrasi di Indonesia, Studi Tentang Keberadaan PTUN Selama Satu Dasawarsa 1991-2001, (Jakarta: Perum Percetakan Negara RI, 2005), hlm 42-43

$$
\sim 105 \sim
$$


dan/atau tindakan Pejabat Pemerintah dan atau Badan Hukum lainnya yang menggunakan diskresi dapat diuji melalui gugatan di Peradilan Tata Usaha Negara. Selanjutnya mengenai dasar pengujian Pengadilan Tata Usaha Negara dalam memeriksa suatu perkara termasuk didalamnya adalah terhadap keputusan yang berupa keputusan diskresi adalah pertama-tama dengan mendasarkan pada ketentuan Pasal 1 angka 12 Undang-Undang Nomor 51 Tahun 2009 tentang Peradilan Tata Usaha Negara yang menyebutkan bahwa Tergugat adalah Badan atau Pejabat Tata Usaha Negara yang mengeluarkan keputusan berdasarkan wewenang yang ada padanya atau yang dilimpahkan kepadanya, yang digugat oleh orang atau badan hukum perdata.

Berdasarkan latar belakang sebagaimana dikemukakan di atas, maka perumusan masalah dalam penelitian ini adalah : Petama: Siapakah Badan/Pejabat pemerintahan yang dapat menerbitkan keputusan diskresi?. Kedua: Bagaimanakah bentuk diskresi pejabat pemerintahan yang dapat diuji oleh pengadilan tata usaha negara pasca berlakunya Undang-undang Nomor 30 Tahun 2014 Tentang Administrasi Pemerintahan? Dan, Ketiga: Bagaimana praktik Pengadilan Tata Usaha Negara dalam menguji keputusan diskresi yang dikeluarkan oleh pejabat pemerintahan ?

Tujuan dari penelitian ini dibedakan menjadi 2 (dua) yaitu tujuan secara praktis dan akademis. Secara praktis tujuan dari penelitian ini adalah untuk mengetahui dan memberi gambaran mengenai keputusan-keputusan diskresi yang telah diterbitkan oleh Badan/Pejabat Administrasi Pemerintahan dan manakala keputusan-keputusan tersebut digugat, bagaimana pengujiannya dilakukan oleh Pengadilan Tata Usaha Negara. Sedangkan tujuan secara akademis dari penelitian ini adalah untuk menemukan asas hukum bahwa pengujian terhadap keputusan diskresi tidak dapat dilakukan dengan mendasarkan pada Pasal 53 ayat (2) huruf a dan b Undang-Undang Nomor 9 Tahun 2004, melainkan secara kasuistis diuji dengan menggunakan asas-asas umum pemerintahan baik. Sedangkan Hasil penelitian ini secara praktis diharapkan dapat menjadi acuan yang dapat menunjang tugas Badan/Pejabat Administrasi Pemerintahan dalam menerbitkan keputusan diskresi, sebaliknya bagi Pengadilan Tata Usaha Negara agar memiliki acuan dalam menguji keputusan-keputusan yang lahir dari kewenangan diskresi. Sedangkan secara akademis diharapkan dapat menemukan asas-asas hukum dalam pengujian keputusan diskresi oleh Pengadilan Tata Usaha Negara yang memperkaya wacana ilmiah dibidang hukum administrasi Negara.

\section{Metode Penelitian}

Penelitian ini menggunakan pendekatan yuridis normatif berupa pendekatan kasus (penelitian hukum in concreto). Metode pendekatan yuridis normatif dalam hal ini suatu pendekatan dimana hukum dikonsepsikan sebagai asas-asas hukum ${ }^{9}$. Disamping itu digunakan juga pendekatan kasus yaitu pendekatan dengan cara melakukan telaah terhadap kasus-kasus yang berkaitan dengan isu yang dihadapi yang telah menjadi

${ }^{9}$ Sorjono Soekanto didalam bukunya Pengantar Penelitian Hukum, (Jakarta: UI Press, 1986), hlm 51 
putusan pengadilan khususnya putusan yang telah berkekuatan hukum tetap ${ }^{10}$. Dalam pendekatan ini, hukum tidak sematamata dikonsepsikan sebagai norma, tetapi juga sebagai produk yang terwujud lewat proses judisial dari kasus ke kasus, yang acap disebut "hukum in concreto" yang kemudian akan ditarik suatu asas hukum. Kumpulan putusan Hakim yang mengakhiri perkara macam ini disebut jurisprudentie dalam bahasa belanda dan judge made laws dalam tradisi hukum di negeri-negeri penganut common law system ${ }^{11}$.

Permasalahan akan dianalisis dengan menggunakan peraturan perundangundangan, asas-asas umum pemerintahan yang baik, Putusan Pengadilan Tata Usaha Negara, serta pendapat para ahli hukum. Untuk mencapai kejelasan masalah yang akan dibahas akan digunakan metode berpikir induktif yaitu metode berpikir yang mendasarkan pada hal-hal yang bersifat khusus untuk kemudian ditarik kesimpulan yang bersifat umum.

\section{Hasil Penelitian dan Pembahasan}

Pengujian Keputusan Oleh Pengadilan Tata Usaha Negara Terhadap Diskresi Yang Dilakukan Oleh Pejabat Pemerintahan dalam praktek perkara di Peradilan Tata Usaha Negara akan diketahui melalui Putusan-putusan pengadilan khususnya putusan pengadilan yang telah memperoleh kekuatan hukum tetap. Alasan mengapa pembahasan terhadap permasalahan dilakukan dengan instrumen putusan Pengadilan karena menurut Artidjo Alkostar ${ }^{12}$, putusan pengadilan merupakan bagian dari proses penegakan hukum yang bertujuan untuk mencapai kebenaran dan keadilan. Putusan pengadilan merupakan produk penegak hukum yang didasarkan pada hal-hal yang relevan secara yuridis yang muncul secara sah di persidangan. Kualitas putusan pengadilan berkorelasi dengan profesionalisme, kecerdasan moral, dan kepekaan nurani Hakim.

Jadi, suatu putusan dapat sekaligus mengandung 2 (dua) unsur yaitu di satu pihak putusan merupakan penyelesaian atau pemecahan suatu peristiwa konkrit dan di pihak lain merupakan peraturan hukum untuk waktu mendatang ${ }^{13}$. Oleh karenanya Artidjo Alkostar mengatakan bahwa dalam upaya untuk menemukan dan menerapkan keadilan dan kebenaran, putusan pengadilan harus sesuai dengan tujuan asasi dari suatu putusan pengadilan yaitu :

1) Harus melakukan solusi autoritatif, artinya memberikan jalan keluar dari masalah hukum yang dihadapi oleh para pihak.

2) Harus mengandung efisiensi yaitu sederhana, cepat dan biaya ringan karena keadilan yang tertunda itu merupakan ketidakadilan.

${ }^{10}$ Peter Mahmud Marzuki, Penelitian Hukum, (Jakarta: Prenada Media Group, 2008), hlm 94

11 Soetandyo Wignyosoebroto, Keragaman Dalam Konsep Hukum, Tipe Kajian dan Metode Penelitiannya, dalam Butir-Butir Pemikiran Dalam Hukum Memperingati 70 Tahun Prof. Dr. B. Arief Sidharta, SH, (Bandung: Refika Aditama, 2008), hlm 45

${ }^{12}$ Artidjo Alkostar, Dimensi Kebenaran Dalam Putusan Pengadilan, Varia Peradilan, April 2009, hlm 36

${ }^{13}$ Sudikno Mertokusumo, Op Cit, hlm 37 
Volume 13, Nomor 1, Januari-Juni 2018

3) Harus sesuai dengan tujuan undang-undang yang dijadikan dasar putusan pengadilan tersebut.

4) Harus mengandung aspek stabilitas, yaitu ketertiban sosial dan ketentraman masyarakat.

5) Harus ada fairness, yaitu memberi kesempatan yang sama bagi pihak yang berperkara ${ }^{14}$.

\section{A. Kasus Perkara Pemberhentian Tidak Dengan Hormat 4 (empat) orang Pegawai Perusahaan Daerah Bank Perkreditan Rakyat Bank Pasar Kabupaten Kebumen.}

Dalam kasus ini, Para Penggugat M. Budi Waluyo, SE, Sri Budiarti, Sugiarti dan Siti Jaimah sebagai para karyawan PD. BPR Bank Pasar Kabupaten Kebumen telah diberhentikan tidak dengan hormat oleh Bupati Kebumen karena diduga telah terlibat dalam kasus kredit fiktif yang terjadi di PD. BPR Bank Pasar Kabupaten Kebumen. Secara atributif, kewenangan untuk memberhentikan pegawai PD. BPR Bank Pasar Kabupaten Kebumen diatur didalam Pasal 37 huruf b Peraturan Menteri Dalam Negeri Nomor. 22 Tahun 2006 yang menyatakan bahwa "Direksi mempunyai wewenang mengangkat dan memberhentikan pegawai BPR Daerah berdasarkan peraturan kepegawaian BPR Daerah yang bersangkutan.

Demikian pula dalam Pasal 18 huruf b Peraturan Daerah Kabupaten Kebumen Nomor 2 Tahun 2002 juga dinyatakan bahwa "Direksi mengangkat dan memberhentikan pegawai berdasarkan peraturan kepegawaian yang ditetapkan oleh Direksi dengan persetujuan Bupati melalui Dewan Pengawas berdasarkan peraturan perundang-undangan yang berlaku".

Dengan demikian kewenangan Direksi untuk memberhentikan pegawai PD. BPR Bank Pasar Kabupaten Kebumen diperoleh secara atributif dan bukan berasal dari kewenangan delegasi. Tetapi karena suatu keadaan mendesak dimana terjadi kredit fiktif yang diduga merugikan PD. BPR Bank Pasar Kabupaten Kebumen senilai lebih dari 1,5 Milyar Rupiah menyebabkan seluruh Anggota Direksi juga telah diberhentikan terlebih dahulu oleh Bupati Kebumen, maka Direksi yang secara atributif berwenang untuk memberhentikan pegawai PD. BPR Bank Pasar Kabupaten Kebumen, tidak dapat melaksanakan tugasnya karena pada saat Penggugat diberhentikan, pada saat itu yang ada adalah Pejabat Sementara Direktur Utama. Dalam keadaan yang demikian, Bupati Kebumen telah mengambil suatu kebijakan untuk menerbitkan keputusan pemberhentian Para Penggugat dengan mendasarkan pada Keputusan Gubernur Jawa Tengah Nomor : 64/Tahun 2002 tanggal 13 Mei 2002 yang menyatakan Pejabat Sementara (Pjs), Pejabat Pelaksana Tugas (Plt), Pejabat Pelaksana Harian (Plh) dan Pejabat Yang Menjalankan Tugas (Ymt) tidak berwenang untuk menetapkan kebijakan yang bersifat mengikat seperti penetapan surat keputusan dan penjatuhan hukuman disiplin.

\footnotetext{
${ }^{14}$ Artidjo Alkostar, Op Cit hlm 37
} 
Atas tindakan Tergugat tersebut, PTUN Semarang didalam Putusan Nomor. 48/G/2008/PTUN.SMG, 49/G/2008/PTUN.SMG, 50/G/2008/PTUN.SMG, dan 51/G/2008/PTUN.SMG masing-masing tanggal 2 April 2009 telah membenarkan tindakan Bupati Kebumen tersebut meskipun secara atributif kewenangan untuk memberhentikan pegawai PD. BPR Bank Pasar Kabupaten Kebumen berada di tangan direksi dengan alasan keadaan yang mendesak dan demi kepentingan umum serta tidak berwenangnya Pejabat Sementara (PJS) Direktur Utama untuk memberhentikan pegawai PD. BPR Bank Pasar Kabupaten Kebumen. Meskipun dalam pokok perkaranya gugatan Para Penggugat dikabulkan untuk selurhnya, akan tetapi dari segi kewenangan, Bupati Kebumen dinyatakan berwenang untuk menerbitkan surat keputusan obyek sengketa. Selanjutnya berdasarkan Putusan Pengadilan Tinggi Tata Usaha Negara Surabaya Nomor. 77/B/2009/PT.TUN.SBY, 78/B/2009/PT.TUN.SBY, 79/B/2009/PT.TUN.SBY, 80/B/2009/PT.TUN.SBY masing-masing di putus pada tanggal 10 Agustus 2009, telah menguatkan putusan Pengadilan Tata Usaha Negara Semarang sebagaimana disebut diatas sehingga telah berkekuatan hukum tetap.

\section{B. KASUS PEMBERHENTIAN DAN PENGANGKATAN DALAM JABATAN STRUKTURAL ESELON II / ADMINISTRATOR DI LINGKUNGAN PEMERINTAH KABUPATEN BENER MERIAH}

Dalam kasus ini, Penggugat Mahyuddin, S.T., M.M. sebagai Pejabat Struktural Eselon II / Administrator Di Lingkungan Pemerintah Kabupaten Bener Meriah yaitu Kepala pada Dinas Bina Marga dan Cipta Karya Kabupaten Bener Meriah / eselon (II.b) telah diganti dengan tanpa jabatan / eselon berupa Pelaksana pada Badan Kepegawaian, Pendidikan dan Pelatihan Kabupaten Bener Meriah oleh Plt. Bupati Bener Meriah Kebumen. Secara atributif, kewenangan untuk memutasi pegawai Di Lingkungan Pemerintah Kabupaten Bener Meriah diatur dalam Pasal 132A Peraturan Pemerintah Nomor 6 Tahun 2005 tentang Pemilihan, Pengesahan Pengangkatan, dan Pemberhentian Kepala Daerah dan Wakil Kepala Daerah sebagaimana telah diubah untuk terakhir kali dengan Peraturan Pemerintah Nomor 78 Tahun 2012 tentang Perubahan Keempat atas PP Nomor 6 Tahun 2005 tentang Pemilihan, Pengesahan Pengangkatan, dan Pemberhentian Kepala Daerah dan Wakil Kepala Daerah menentukan: (1) Penjabat kepala daerah atau pelaksana tugas kepala daerah sebagaimana dimaksud dalam Pasal 130 ayat (1) dan ayat (3), serta Pasal 131 ayat (4), atau yang diangkat untuk mengisi kekosongan jabatan kepala daerah karena mengundurkan diri untuk mencalonkan/dicalonkan menjadi calon kepala daerah / wakil kepala daerah, serta kepala daerah yang diangkat dari wakil kepala daerah yang menggantikan kepala daerah yang mengundurkan untuk mencalonkan/dicalonkan sebagai calon kepala daerah/wakil kepala daerah dilarang:

a. melakukan mutasi pegawai;

b. membatalkan perijinan yang telah dikeluarkan pejabat sebelumnya dan/atau mengeluarkan perijinan yang bertentangan dengan yang dikeluarkan pejabat sebelumnya; 
c. membuat kebijakan tentang pemekaran daerah yang bertentangan dengan kebijakan pejabat sebelumnya; dan

d. membuat kebijakan yang bertentangan dengan kebijakan penyelenggaraan pemerintahan dan program pembangunan pejabat sebelumnya.

Bahwa Bupati dan wakil Bupati Kabupaten Bener Meriah ditetapkan sebagai Bupati Kabupaten Bener Meriah setelah melalui pesta Demokrasi Pemilukada Tahun 2012. Bupati Bener Meriah pada Maret 2016 ditetapkan sebagai Tersangka oleh KPK RI serta ditahan untuk kepentingan penyidikan atas dugaan penyalahgunaan kewenangannya sebagai kepala BPKS Sabang pada Tahun 2011. Untuk itu Menteri Dalam Negeri melalui Suratnya Nomor 132.11/999/SJ kepada Gubernur Aceh Perihal Penugasan Wakil Bupati Bener Meriah selaku Pelaksana Tugas Bupati Bener Meriah tanggal 24 Maret 2016 berdasarkan Undang-undang Nomor 9 Tahun 2015 tentang Perubahan kedua atas Undang-Undang Nomor 23 Tahun 2014 tentang Pemerintah Daerah. Dalam Pasal 65 ayat (3) menyatakan "Kepala Daerah yang sedang menjalani masa tahanan dilarang melaksanakan tugas dan kewenangannya" selanjutnya Pasal 66 ayat (1) huruf C menyatakan "Wakil Kepala Daerah melaksanakan Tugas dan Wewenang kepala daerah apabila kepala daerah menjalani masa tahanan atau berhalangan sementara". Sehingga sejak tanggal 24 Maret 2016 sesuai dengan surat perintah Gubernur Aceh Nomor 04/Sprint/2016 tanggal 24 Maret 2016 Wakil Bupati Bener Meriah ditunjuk sebagai Pelaksana Tugas Bupati Bener Meriah. Untuk itu berdasarkan ketentuan tersebut kewenangannya dengan Bupati adalah sama.

Penggugat juga mendalilkan dalam gugatannya terkait dengan kewenangan Pejabat Kepala Daerah berdasarkan Surat Kepala Badan Kepegawaian Negara Nomor: K.2630/V.100-2/99 tanggal 19 Oktober 2015 menyatakan bahwa Tergugat tidak memiliki kewenangan mengambil atau menetapkan keputusan yang memiliki akibat hukum pada aspek kepegawaian untuk melakukan mutasi pegawai yang berupa pengangkatan, pemindahan, dan pemberhentian dalam/dari jabatan ASN, menetapkan hukuman disiplin yang berupa pembebasan dari jabatan atau pemberhentian dengan hormat tidak atas permintaan sendiri sebagai Pegawai Negeri Sipil, Kecuali setelah mendapat persetujuan tertulis dari Menteri Dalam Negeri;

Atas tindakan Tergugat tersebut, PTUN Banda Aceh didalam Putusan Nomor. 31/G/2016/PTUN.BNA, tanggal 13 Februari 2017 tidak membenarkan tindakan Bupati Bener Meriah karena dalam Surat Kepala Badan Kepegawaian Negara Nomor: K .26-30 IV .1OO -2 | 99 tanggal 19 Oktober 2015 Perihal Penjelasan atas kewenangan penjabat kepala daerah di bidang kepegawaian menyatakan pada Poin 2 huruf a "Penjabat kepala daerah tidak memiliki kewenangan mengambil atau menetapkan keputusan yang memiliki akibat hukum (civil effect) pada aspek kepegawaian untuk melakukan mutasi pegawai yang berupa pengangkatan, pemindahan, dan pemberhentian dalam/dari jabatan ASN, menetapkan keputusan hukuman disiplin yang berupa pembebasan dari jabatan atau pemberhentian dengan hormat tidak atas permintaan sendiri sebagai pegawai negeri sipil, kecuali setelah mendapat persetujuan tertulis dari Menteri Dalam Negeri" sehingga gugatan dikabulkan dan Surat Keputusan yang dijadikan objek sengketa dinyatakan tidak 
sah. Selanjutnya berdasarkan Putusan Pengadilan Tinggi Tata Usaha Negara Medan Nomor. 77/B/2017/PT.TUN.MDN, telah menguatkan putusan Pengadilan Tata Usaha Negara Banda Aceh sebagaimana disebut diatas sehingga telah berkekuatan hukum tetap.

\section{PENGUJIAN KEPUTUSAN DISKRESI PEJABAT PEMERINTAHAN OLEH PENGADILAN TATA USAHA NEGARA}

\section{A. Badan/Pejabat Pemerintahan Yang Dapat Menerbitkan Keputusan Diskresi.}

Berdasarkan praktik sidang pada peradilan tata usaha negara, jabatan-jabatan seperti:

a. Presiden;

b. Para Menteri atau Pejabat setingkat Menteri;

c. Panglima TNI dan Kepala Staf Angkatan Darat, Laut dan Udara;

d. Kepala Kepolisian Negara;

e. Ketua Komisi/Dewan dan Lembaga setara;

f. Gubernur;

g. Bupati dan Walikota;

h. Pejabat Eselon I di Pemerintah Pusat dan Provinsi;

i. Sekretraris Daerah Kabupaten/Kota;

j. Pimpinan Badan. Serta pejabat operasional yang memiliki kewenangan untuk menetapkan keputusan diskresi karena tugasnya berhubungan langsung dengan pelayanan masyarakat seperti:

1) Kepala resort Kepolisian Negara;

2) Camat.

pada prinsipnya setiap pejabat yang menjalankan urusan pemerintahan yang memiliki kewenangan secara atributif maupun delegasi memiliki kewenangan diskresi karena kewenangan diskresi merupakan pelengkap dari asas legalitas. Contoh jabatan lain yang juga memiliki kewenangan diskresi antara lain Lurah/Kepala Desa, Ketua BPD (Badan Permusyawaratan Desa) dan Direktur BUMD bahkan Polisi sebagai penyidik dan Jaksa sebagai Penuntut Umum memiliki diskresi terhadap perkara-perkara tertentu yang tidak ditindaklanjuti ke persidangan dengan alasan kemanfaatan serta Hakim pun memiliki kewenangan diskresi sebagaimana telah diuraikan diatas.

Sebagaimana asas hukum bahwa tidak ada aturan tanpa pengecualian, maka ada pula pejabat-pejabat yang dikecualikan dari kewenangan menerbitkan keputusan diskresi antara lain pejabat sementara, pejabat yang menjalankan tugas, pelaksana tugas dan pejabat pelaksana harian (Pjs, Ymt, Plt dan Plh) karena bukan pejabat definitif, maka pada prinsipnya tidak dapat menerbitkan keputusan yang bersifat strategis seperti pengangkatan dan pemberhentian pegawai serta keputusan-keputusan yang berkaitan dengan keuangan terlebih-lebih keputusan yang bersifat diskresi. Akan tetapi yang perlu diperhatikan adalah bahwa dalam hal pejabat definitif yang memperoleh kewenangan secara delegasi tidak ada (berhalangan dalam waktu yang cukup lama) padahal ia harus menerbitkan suatu keputusan diskresi, maka pejabat yang mendelegasikan 
Volume 13, Nomor 1, Januari-Juni 2018

kewenangannya harus mencabut keputusan pemberian delegasi baru kemudian dapat menerbitkan keputusan diskresi. Namun pernah terjadi pejabat yang memperoleh kewenangan secara atributif tidak ada karena telah diberhentikan padahal pejabat tersebut harus menerbitkan keputusan diskresi, maka atasan langsung pejabat definitif tersebut dapat menerbitkan keputusan diskresi jika ada keadaan yang mendesak dan dilakukan untuk kepentingan umum. Atas dasar hal tersebut, maka seyogyanya kewenangan menerbitkan keputusan diskresi harus diberikan kepada setiap pejabat yang memperoleh kewenangan secara atributif dan delegasi dengan pengecualian-pengecualian sebagaimana disebut diatas.

\section{B. Diskresi Pejabat Pemerintahan Yang Dapat Diuji Oleh Pengadilan Tata Usaha Negara Pasca Berlakunya Undang-Undang Nomor 30 Tahun 2014 Tentang Administrasi Pemerintahan}

Dalam menyelenggarakan tugas administrasi negara, pemerintah banyak mengeluarkan kebijakan yang dituangkan dalam berbagai bentuk seperti beleidslijnen( garis-garis kebijakan), het beleid ( kebijakan), vvorschriften (peraturan -peraturan), richtlijnen (pedoman-pedoman), regelingen ( petunjuk-petunjuk) circularizes ( surat edaran), resoluties ( resolusi-resolusi), aanschrijivingen (instruksi-instruksi), beleidsnota (nota kebijakan), reglemen (peraturan-peraturan menteri), beschikking (keputusankeputusan). ${ }^{15}$

Menurut Phillipus M. Hadjon, peraturan kebijakan pada hakikatnya merupakan produk dari perbuatan tata usaha negara yang bertujuan untuk menampakan keluar suatu kebijakan tertulis ${ }^{16}$.

Produk hukum dari Badan/Pejabat administrasi pemerintahan yang berupa dokumen-dokumen yang mengandung materi penetapan yang bersifat konkrit, individual dan final dalam hukum administrasi disebut dengan keputusan (Beschikking), sedangkan dokumen-dokumen yang mengandung materi pengaturan yang bersifat umum disebut peraturan (regeling). Adapun perizinan (vergunning) merupakan suatu bentuk pengecualian dari larangan yang terdapat dalam suatu peraturan. Instrumen pemerintahannya dituangkan dalam bentuk peraturan mengenai izin atas hal tertentu, sedangkan landasan pelaksanaan/operasional bagi masyarakat atau badan/pejabat administrasi pemerintahan adalah berupa keputusan administrasi pemerintahan mengenai izin atas hal tertentu.Sedangkan peraturan kebijaksanaan ${ }^{17}$ (beleid regels), adalah merupakan produk hukum yang lahir dari kewenangan mengatur kepentingan umum secara mandiri atas dasar prinsip freies ermessen ${ }^{18}$ yang dalam praktek banyak ditemukan

${ }^{15}$ Ridwan HR, Hukum Administrasi Negara, (Jakarta : PT. Raja Grafindo Persada, 2007), hlm 136-137

${ }^{16}$ Phillipus m. Hadjon (et al), pengantar Hukum Administrasi Indonesia, (Yogyakarta: Gajah Mada University Press, 1999), hlm 152

17 Beberapa Pakar Hukum seperti Bagir Manan, Anna Erliyanna, menggunakan istilah peraturan kebijakan

18 Jimly Asshiddiqie, Format Kelembagaan Negara dan Pergeseran Kekuasaan Dalam UUD 1945, (Yogyakarta: FH UII Press, 2004), hlm 25 
dituangkan dalam bentuk Keputusan Presiden atau Keputusan Menteri. Akibatnya banyak sekali Keputusan Presiden yang ditetapkan, termasuk berkenaan dengan sesuatu materi ketentuan yang seharusnya dituangkan dalam bentuk Undang-Undang, ditetapkan sendiri oleh Presiden tanpa melibatkan Dewan Perwakilan Rakyat.

Dalam konteks Keputusan Presiden, Anna Erliyanna mengklasifikasikan Keputusan Presiden sebagai tiga hal yaitu sebagai peraturan umum (regeling), keputusan (beschikking), dan peraturan kebijakan (beleidsregel/policy rules) ${ }^{19}$. Oleh karena satu produk hukum berupa Keputusan Presiden dapat diklasifikasikan menjadi tiga hal sebagaimana disebut diatas, maka konsekuensinya adalah bahwa untuk menguji suatu Keputusan Presiden tidak dapat dilihat pada nomenklaturnya saja, akan tetapi harus dilihat materi muatannya apakah sebagai peraturan umum (regeling), keputusan (beschikking), atau peraturan kebijakan (beleidsregel/policy rules), sebab lembaga yang berwenang menguji legalitasnya berbeda-beda. Apabila Keputusan Presiden sebagai suatu peraturan umum dan sebagai suatu peraturan kebijakan (beleidsregel/policy rules), maka lembaga yang berwenang untuk menguji legalitasnya adalah Mahkamah Agung melalui hak uji materil, sedangkan apabila Keputusan Presiden sebagai suatu keputusan (beschikking), maka lembaga yang berwenang untuk menguji legalitasnya adalah Pengadilan Tata Usaha Negara. Akan tetapi dalam bentuknya sebagai suatu peraturan kebijakan (beleidsregel/policy rules), Bagir Manan mengatakan bahwa peraturan kebijakan bukan peraturan perundang-undangan sehingga asas-asas pembatasan dan pengujian terhadap peraturan perundang-undangan tidak dapat diberlakukan pada peraturan kebijakan.

\section{Pengujian Keputusan Diskresi Yang Dikeluarkan Oleh Pejabat Pemerintahan Dalam Praktik Perkara Di Pengadilan Tata Usaha Negara.}

Hakim Pengadilan Tata Usaha Negara hanya dapat memeriksa Keputusan Diskresi apabila didasarkan dugaan terdapatnya kesalahan dalam menetapkan diskresi oleh Pejabat Administrasi Pemerintahan dan seluruh upaya administratif sudah ditempuh. Selanjutnya dalam melakukan pengujian terhadap keputusan diskresi, maka dasar pengujian yang digunakan oleh Hakim Pengadilan Tata Usaha Negara adalah asas-asas umum pemerintahan yang baik (AUPB).

Karena sifatnya yang mendesak, maka sebaiknya perkara yang obyek sengketanya keputusan diskresi, diperiksa dengan acara cepat agar segera diperoleh putusan hukum atas keputusan diskresi tersebut sehingga acara cepat tersebut harus dimohonkan oleh Penggugat di dalam gugatannya. Oleh karena itu sejak gugatan di daftarkan di Kepaniteraan, maka Panitera harus menyarankan agar permohonan perkara diperiksa dengan acara cepat dimuat didalam gugatan Penggugat.

Pengujian keputusan diskresi dalam praktik perkara di Peradilan Tata Usaha Negara akan diketahui melalui putusan-putusan pengadilan khususnya putusan pengadilan yang telah memperoleh kekuatan hukum tetap. Alasan mengapa pembahasan

19 Anna Erliyanna, Keputusan Presiden, Analisis Keppres RI 1987-1998, Program Pasca Sarjana Fakultas Hukum Universitas Indonesia, Jakarta, 2005, hlm 131 
Volume 13, Nomor 1, Januari-Juni 2018

terhadap permasalahan dilakukan dengan instrumen putusan Pengadilan karena menurut Artidjo Alkostar, ${ }^{20}$ putusan pengadilan merupakan bagian dari proses penegakan hukum yang bertujuan untuk mencapai kebenaran dan keadilan. Putusan pengadilan merupakan produk penegak hukum yang didasarkan pada hal-hal yang relevan secara yuridis yang muncul secara sah dipersidangan. Kualitas putusan pengadilan berkolerasi dengan propesionalisme, kecerdasan moral dan kepekaan nurani hakim . Pertimbangan Hukum (Legal Reasoning) yang dipakai para hakim sebagai landasan dalam mengeluarkan amar putusan, merupakan determinan dalam melihat kualitas putusan.

Dalam pasal 49 Undang-undang Nomor 5 tahun 1986 secara lengkap menyebutkan

“ Pengadilan tidak berwenang memeriksa, memutus, dan menyelsaikan sengketa tata usaha negara tertentu dalam hal keputusan yang disengketakan itu dikeluarkan :

a. Dalam waktu perang, keadaan bahaya, keadaan bencana alam, atau keadaan luar biasa yang membahayakan berdasarkan peraturan perundang-undangan yang berlaku ;

b. Dalam keadaan mendesak untuk kepentingan umum berdasrkan peraturan perundang-undangan yang berlaku.

Didalam penjelasan pasal 49 hanya dijelaskan yang dimaksud dengan "kepentingan umum" adalah kepentingan bangsa dan negara dan/atau kepentingan masyarakat bersama dan/atau kepentingan pembangunan, sesuai dengan peraturan perundang-undangan yang berlaku.

Beberapa keputusan diskresi didalam praktik seringkali didalilkan oleh Tergugat sebagai keputusan yang diterbitkan dalam keadaan mendesak dan untuk kepentingan umum, baik yang disebutkan didalam keputusan objectum litis, maupun didalilkan didalam jawaban Tergugat pada saat terjadi gugatan.

Untuk membuktikan apakah suatu keputusan benar diterbitkan dalam keadaan mendesak serta apakah suatu keputusan dierbitkan untuk kepentingan umum ataukah tidak, maka majelis hakim yang memeriksa perkara tersebut perlu untuk memeriksa dan mempertimbangkan bukti-bukti yang diajukan oleh para pihak dipersidangan, sehingga dengan demikian pemeriksaan dan pertimbangan Majelis Hakim sudah masuk pada pokok perkara bukan hanya pada formalitas gugatan. Apabila berdasarkan bukti-bukti yang diajukan oleh para pihak, majelis hakim menemukan fakta hukum bahwa keptusan yang digugat diterbitkan bukan dalam keadaan yang mendesak dan bukan untuk kepentingan umum, maka sudah seharusnya menurut hukum gugatan tersebut dikabulkan dan obyek gugatan dinyatakan batal, apabila berdasarkan bukti-bukti yang diajukan oleh para pihak ternyata keputusan yang digugat memang diterbitkan dalam keadaan yang mendesak dan demi kepentingan umum, maka sudah seharusnya pula menurut hukum gugatan dinyatakan ditolak.

${ }^{20}$ Artidjo Alkostar, Dimensi Kebenaran Dalam Putusan Pengadilan, Varia Peradilan, April 2009, hal. 36 
Volume 13, Nomor 1, Januari-Juni 2018

\section{Penutup}

Bahwa Badan/Pejabat Administrasi Pemerintahan yang menerbitkan keputusan diskresi haruslah memiliki kewenangan untuk menerbitkan keputusan diskresi baik kewenangan yang berkaitan dengan cara memperoleh kewenangan yaitu atribusi atau delegasi ataupun kewenangan yang menyangkut wilayah, materi dan waktu. Selanjutnya, diskresi hanya dikeluarkan oleh pemerintah (eksekutif) baik ditingkat pusat maupun ditingkat daerah beserta seluruh jajarannya karena dalam penggunaan kebijakan diskresi yang melanggar atau merugikan hak warga negara terhadap pemerintah (eksekutif) dapat dimintai pertanggungjawaban melalui pengadilan.

Bahwa Produk hukum dari Badan/Pejabat pemerintahan yang dapat dijadikan objek sengketa dan diuji pada pengadilan Tata Usaha Negara berupa dokumen-dokumen yang mengandung materi penetapan yang bersifat konkrit, individual dan final dalam hukum administrasi disebut dengan keputusan (Beschikking) dan tindakan sedangkan dokumen-dokumen yang mengandung materi pengaturan yang bersifat umum disebut peraturan (regeling) tidak dapat dijadikan objek sengketa dan tidak dapat diuji di pengadilan Tata Usaha Negara. Kemudian, dalam hal ada suatu aturan yang mengatur tentang hal tertentu, akan tetapi aturan tersebut tidak memungkinkan untuk dilaksanakan, maka pengujian terhadap keputusan diskresi oleh Pengadilan Tata Usaha Negara dilakukan tidak dengan menggunakan peraturan perundang-undangan yang berlaku, melainkan dengan asas-asas umum pemerintahan yang baik (AUPB).

Bahwa Dasar diterbitkannya keputusan diskresi adalah adanya keadaan mendesak yaitu suatu keadaan yang muncul secara tiba-tiba menyangkut kepentingan umum yang harus diselesaikan dengan cepat, dimana untuk menyelesaikan persoalan tersebut, peraturan perundang-undangan belum mengaturnya atau hanya mengatur secara umum dan keadaan tersebut tidak boleh tercipta karena kesalahan tindakan oleh Badan atau Pejabat Administrasi Pemerintahan yang melakukan diskresi. Kemudian, merujuk pada pasal 53 ayat (2) huruf a dan b Undang-Undang Nomor 5 Tahun 1986 jo Undang-Undang Nomor 9 Tahun 2004, maka diskresi yang dapat diuji oleh Pengadilan Tata Usaha Negara sebatas pada keputusan dan tindakan diskresi karena berdasarkan peraturan perundangundangan yang berlaku dan prospeknya juga dapat dilakukan terhadap tindakan faktual serta dapat pula memutus mengenai ganti rugi atas kerugian materil sebagai akibat diterbitkannya keputusan diskresi yang tidak terbatas hanya maksimal sebesar Rp. 5.000.000,- (lima juta rupiah).

\section{Daftar Pustaka}

\section{A. Buku}

Anna Erliyanna, Keputusan Presiden, Analisis Keppres RI 1987-1998, Program Pasca Sarjana Fakultas Hukum Universitas Indonesia, Jakarta, 2005

Anna Erliyanna, Keputusan Presiden, Analisis Keppres RI 1987-1998, Program Pasca Sarjana Fakultas Hukum Universitas Indonesia, Jakarta, 2005 
Volume 13, Nomor 1, Januari-Juni 2018

Artidjo Alkostar, Dimensi Kebenaran Dalam Putusan Pengadilan, Varia Peradilan, April 2009

Ridwan HR, Hukum Administrasi Negara, PT. Raja Grafindo Persada, Jakarta 2007

Artidjo Alkostar, Dimensi Kebenaran Dalam Putusan Pengadilan, Varia Peradilan, April 2009

Jimly Asshiddiqie, Format Kelembagaan Negara dan Pergeseran Kekuasaan Dalam UUD 1945, FH UII Press, Yogyakarta 2004

Lintong Oloan Siahaan, Prospek PTUN sebagai Pranata Penyelesaian Sengketa Administrasi di Indonesia, Studi Tentang Keberadaan PTUN Selama Satu Dasawarsa 1991-2001, Perum Percetakan Negara RI, Jakarta, 2005

Lintong Oloan Siahaan, Wewenang PTUN menunda berlakunya Keputusan Pemerintah, Perum Percetakan Negara RI, Jakarta, 2006

Marbun, SF, Menggali dan Menemukan Asas-asas Umum Pemerintahan yang Baik Di Indonesia, dalam SF Marbun dkk, Dimensi-Dimensi Pemikiran Hukum Administrasi Negara, UII Press, Yogyakarta 2001

Marcus Lukman sebagaimana dikutip oleh Saut P. Panjaitan, Makna dan Peranan Freies Ermessen Dalam Hukum Administrasi Negara dalam SF Marbun dkk, Dimensi-Dimensi Pemikiran Hukum Administrasi Negara, UII Press, Yogyakarta 2001

Muhammad Siddiq Armia, Mahkamah Konstitusi Dan Pengujian Undang-Undang: Pembelajaran Bagi Indonesia, Jurnal NEGARA HUKUM: Vol. 8, No. 1, Juni 2017

Patuan Sinaga, Hubungan antara kekuasaan dengan Pouvoir Discretionnaire Dalam Penyelenggaraan Pemerintahan dalam SF Marbun dkk, Dimensi-Dimensi Pemikiran Hukum Administrasi Negara, UII Press, Yogyakarta 2001

Penelitiannya, dalam Butir-Butir Pemikiran Dalam Hukum Memperingati 70 Tahun Prof. Dr. B. Arief Sidharta, SH, Refika Aditama, Bandung, 2008

Peter Mahmud Marzuki, Penelitian Hukum, Prenada Media Group, Jakarta, 2008

Phillipus m. Hadjon (et al), pengantar Hukum Administrasi Indonesia, Gajah Mada University Press, Yogyakarta, 1999

Soetandyo Wignyosoebroto, Masalah Metodologik dalam penelitian Hukum sehubungan dengan Masalah keragaman Pendekatan Konseptual". Makalah disajikan dalam Forum Komunikasi Penelitian Bidang Hukum, Jakarta : Dirbinlatamas, Dirjen Dikti, Depdikbud, 1994, 
Volume 13, Nomor 1, Januari-Juni 2018

Sorjono Soekanto didalam bukunya Pengantar Penelitian Hukum, UI Press, Jakarta, 1986

Zaki Ulya, Pertanggungjawaban Pejabat Pemerintahan dalam Menetapkan Diskresi (Studi terhadap Putusan Mahkamah Konstitusi Nomor 25/PUU-XIV/2016), Jurnal Ius Quia Iustum, Vol 24, No 3, 2017

\section{B. Putusan}

Putusan PTUN Semarang Nomor. 30/G/2008/PTUN.SMG tanggal 26 November 2008

Putusan PT.TUN Surabaya Nomor. 21/B/2009/PT.TUN.SBY tanggal 16 April 2009

Putusan PTUN Banda Aceh Nomor. 31/G/2016/PTUN.BNA tanggal 13 Februari 2017

\section{Peraturan Perundang-undangan}

Undang-Undang Nomor 5 Tahun 1986 tentang Peradilan Tata Usaha Negara (LNRI Tahun 1986 Nomor 77, TLNRI Nomor 3344)

Undang-Undang Nomor 5 Tahun 2004 tentang Mahkamah Agung (LNRI Tahun 2004 Nomor 9, TLNRI Nomor 4359)

Undang-Undang Nomor 9 Tahun 2004 tentang Perubahan Atas Undang-Undang Nomor 5 Tahun1986 tentang Peradilan Tata Usaha Negara (LNRI Tahun 2004 Nomor 35, TLNRI Nomor 4380)

Undang-Undang Nomor 51 Tahun 2009 tentang Perubahan Kedua Atas Undang-Undang Nomor 5 Tahun 1986 Tentang Peradilan Tata Usaha Negara. (LNRI Tahun 2009 Nomor 160, TLNRI Nomor 5079)

Undang-Undang Nomor 12 Tahun 2011 tentang Pembentukan Peraturan Perundangundangan (LNRI Tahun 2011 Nomor 82, TLNRI Nomor 5234)

Undang-Undang Nomor 23 Tahun 2014 tentang Pemerintahan Daerah (LNRI Tahun 2014 Nomor 244, TLNRI Nomor 4380)

Undang-Undang Nomor 30 Tahun 2014 Tentang Administrasi Pemerintahan (LNRI Tahun 2014 Nomor 292, TLNRI Nomor 5587)

Peraturan Pemerintah Nomor 6 Tahun 2005 tentang Pemilihan, Pengesahan Pengangkatan, dan Pemberhentian Kepala Daerah dan Wakil Kepala Daerah (LNRI Tahun 2005 Nomor 22, TLNRI Nomor 4480) 